\title{
Role of Artemisia macrocephala as enzymes inhibitor in dementia and nociception! A pharmacological study
}

\author{
Ismail Shah ${ }^{1}$, Mohammad Shoaib ${ }^{1}$, Niaz Ali ${ }^{2}$, Syed Wadood Ali Shah ${ }^{1}$, \\ Muhammad Asif Nawaz ${ }^{3}$ and Haneef Ur Rehman ${ }^{4 *}$ \\ 1. Department of Pharmacy, University of Malakand, Chakdara, Dir, KPK, Pakistan \\ 2. Department of Pharmacology, Institute of Basic Medical Sciences, Khyber Medical University, Peshawar, KPK, \\ Pakistan \\ 3. Department of Biotechnology, Shaheed Benazir Bhutto University Sheringal, Dir (Upper), KPK, Pakistan \\ 4. Department of Chemistry, University of Turbat, Kech, Turbat, Balochistan, Pakistan \\ *Corresponding author's email: rehman.haneef8@gmail.com \\ Citation \\ Ismail Shah, Mohammad Shoaib, Niaz Ali, Syed Wadood Ali Shah, Muhammad Asif Nawaz and Haneef Ur \\ Rehman. Role of Artemisia macrocephala as enzymes inhibitor in dementia and nociception! A pharmacological \\ study. Pure and Applied Biology. Vol. 5, Issue 3, pp538-546. http://dx.doi.org/10.19045/bspab.2016.50068
}

\begin{tabular}{llll}
\hline Received: 12/04/2016 & Revised: 30/05/2016 & Accepted: 06/06/2016 & Online First: 17/06/2016 \\
\hline \hline
\end{tabular}

\section{Abstract}

This study was conducted for investigating potentials of methanolic extract (Am. CME) and subsequent fractions of Artemisia macrocephala (A. macrocephala) for the inhibition of acetylcholinesterase $(\mathrm{AChE})$, butyrylcholinesterase $(\mathrm{BChE})$ and cyclo-oxygenase $(\mathrm{COX}-1$ and COX-2). Ellman's assay was followed for the investigation of AChE and BChE inhibitory potentials of Am. CME and subsequent fractions of A. macrocephala while cyclo-oxygenase inhibition was investigated using a $\mathrm{COX}$ inhibition assay. For $\mathrm{AChE}$ inhibitory assay, chloroform (Am.CHF), ethyl acetate (Am.EtOAc) fractions and Am.CME showed $85.76 \pm 1.49$, $77.50 \pm 0.86$ and $71.00 \pm 1.15 \%$ inhibition of the enzyme respectively at $1000 \mu \mathrm{g} / \mathrm{mL}$ concentration. Similarly, for BChE inhibition assay, Am.CHF, Am.EtOAc and Am. CME showed $82.56 \pm 0.68,73.56 \pm 1.56$ and $68.55 \pm 0.81 \%$ inhibition of the enzyme respectively at $1000 \mu \mathrm{g} / \mathrm{mL}$ concentration. Am.CHF and Am.CME were found to be most active against COX-1 and COX-2. Against COX-1, AmCHF and Am.CME showed $75.23 \pm 0.98$ and $73.33 \pm 0.46 \%$ inhibition respectively at $1000 \mu \mathrm{g} / \mathrm{mL}$ concentration. Similarly against COX-2, they showed $81.23 \pm 1.23$ and $79.40 \pm 0.46 \%$ respectively at $1000 \mu \mathrm{g} / \mathrm{mL}$ concentration. It can be concluded from results that Artemisia macrocephala can be used in the treatment of cognitive disorders, along with neurodegenerative ailments, various neuro-pharmacological ailments and certain painful conditions.

Key words: Artemisia macrocephala; Acetylcholinesterase; Butyrylcholinesterase; Inhibition

\section{Introduction}

Neurodegenerative disease is a general terminology used for various diseased conditions developing from persistent breakdown and corrosion of neurons in central nervous system. Amongst several types of dementia, Alzheimer's disease (AD) has been common that affect about 20 million people in the world. Owing to its multi-factorial nature, the single therapeutic 
loom is based on the cholinergic hypothesis of cognitive dysfunction [1,2]. $\mathrm{AD}$ is a progressive, neurodegenerative ailment affecting mainly elders and about 50-60\% of dementia patients have age above 65 years. The main symptoms associated with the later stages of $\mathrm{AD}$ engross cognitive dysfunction, principally memory loss leading to sever loss in the abilities of mental level. It affects language, thought and memory control centers of the brain. It is associated with loss in neurons, abnormal tangles and plaques in neurons $[3,4]$.

In mammalian brain, there are present two main types of cholinesterases, namely, acetylcholinesterase (AChE) and butyrylcholinesterase (BuChE) [5]. The common notable biochemical change that $\mathrm{AD}$ patients are facing is diminution of acetylcholine (ACh) level in the brain. $\mathrm{AChE}$ is present in excitable tissues (nerves, muscles, erythrocytes and placenta), while BuChE mostly in peripheral, central nervous system, plasma and liver. Therefore, AChE and BChE inhibition, the enzymes accountable in Ach hydrolysis in cholinergic synapse, is presently the most recognized approach in treatment of $\mathrm{AD}$ [6].

Till date, the treatment of this ailment is based upon "cholinergic hypothesis" meaning that approved drugs for $\mathrm{AD}$ rehabilitation should act through counteracting the Ach deficiency, increasing its level in brain [7].Cholinesterase inhibitors have been developed for improving the efficiency of ACh by arrest in its breakdown and raising its levels in brain or by intensifying the way nerve cells respond to it. ACh high concentration in the brain cause communication amplification among neurons and may momentarily leads to stabilization or improvement of $\mathrm{AD}$ symptoms. These approved drugs are effective in initial and moderate stages of $\mathrm{AD}[8,9]$. Inhibition of enzymes, $\mathrm{AChE}$ and $\mathrm{BuChE}$ is suggested desirable and thought to be among the prime intentions for treatment of AD linked cognitive dysfunction $[10,11]$. At present, frequently used drugs in $\mathrm{AD}$ management are $\mathrm{AChE}$ inhibitors such as physostigmine, tacrine, etc or inhibitors of BuChE like tetrahydro-furo-benzofurancymserine (THFBFC). These all drugs have been proved in improving AD patient's situation to some degree [12]. Presently, Food and Drug Administration (FDA) have approved four drugs to treat A. They are galanthamine, donepezil, rivastigmine, and tacrine. All these drugs are effective in AD patients by slowing down neurodegeneration [13]. Side effects associated are gastrointestinal disturbances; aggression, hepatotoxicity, and depression are the wellknown lim itations of these drugs. In addition, these drugs are costly and require regular blood monitoring [14]. Since the available drugs for $\mathrm{AD}$ management have certain limitations therefore, the exploration of new leading molecules from various natural product sources, which are useful in AD symptoms have gain much more attention.

Several degenerative diseases are commonly related with inflammatory processes like rheumatoid arthritis, gouty arthritis, shoulder tendonitis, cancer and asthma [15, 16]. In inflammatory responses, fatty acids mobilizations are induce by phospholipase A2 activation, particularly arachidonic acid from the membrane lipid pool. Then oxidation of arachidonic acid is carried out by constitutive cyclo-oxygenase -1 (COX-1) or inducible cyclo-oxygenase -2 (COX-2) enzymes, results in prostaglandins production [17]. Prostaglandins belong to inflammatory mediators group, involved in many pain-related disorders [18]. Because of the keen interest in the anti-inflammatory and anti-nociceptive potentials of plants by pharmaceutical firms and scientific work on innovation of new medicinal constituents, plants might be the potential precursor for 
new drugs in the treatment of pain-related conditions with minimum or no side-effects.

\section{Artemisia macrocephala (Artemisia} griffithiana Bioss) is a member of Asteraceae, which has great importance of medicinal values. A. macrocephala, Pashto name "Tarkha", is $20-30 \mathrm{~cm}$ in height, abundantly available in Pakistan especially in northern areas [19]. Camphor, p-cymene, $\alpha$-pinine, $\beta$ - pinine, 1,8-cineole, limonene, camphene, borneol, enanthic acid, propionic acid, isovaleric acid and acetic acid has been isolated from A. macrocephala. [20]. We have previously reported $A$. macrocephala and its essential oil for phytochemical screening and antispasmodic activity [21].We have previously testified antisposmodic potential of different fractions and essential oils of $A$. macrocephala. Antioxidant activity was reported by evaluation of its different fractions [22]. We have reported its essential oil for $\mathrm{AChE}$ and $\mathrm{BuChE}$ inhibition assays with remarkable results [23].

The purpose of recent research work was to investigate the $\mathrm{BChE}, \mathrm{AChE}$ and cyclooxygenase inhibitory potentials of Am.CME and subsequent fractions of $A$. macrocephala in order to explore novel, effective and safest ways to treat $A D$, dementia, other neurological disorders and pain management.

\section{Material and methods}

\section{Chemicals and consumables}

AChE (Electric eel), BChE (equine serum), acetylthiocholine iodide, butyrylthiocholine Iodide, DTNB (5,5-dithio-bis-nitrobenzoic acid) and Galanthamine hydrobromide Lycoris Sp. Were from Sigma-Aldrich, Germany. Extra pure analytical grade $\mathrm{K}_{2} \mathrm{HPO}_{4}, \mathrm{KH}_{2} \mathrm{PO}_{4}$, and $\mathrm{KOH}$ were used for buffer preparation. Indomethacin was obtained from SIZA Pharmaceuticals, Pakistan.

Plant materials collection and authentication
Aerial fresh parts of $A$. macrocephala were collected in August, 2014in hills near Badwan Chowk, Dir Lower, Pakistan. It was identified by Dr. Nasur Ullah, University of Malakand Chakdara, Dir Lower, KPK, Pakistan. Voucher sample "AM-01-2014" has been submitted in University of Malakand herbarium.

\section{Extraction}

Drying of plant material was carried out at room temperature in shade, followed by crushing and mechanical grinding to get fine powder. Soaked the powder $(5.5 \mathrm{~kg})$ for 22 days in commercial grade $(90 \%)$ methanol at room temperature with occasional shaking. Filtration of the materials was carried out. The materials filtered off 3 times. With the help of rotary evaporator at reduced pressure, the combined filtrate was evaporated till obtaining a dark greenish color crude Am.CME. yielding 555 gram (10.09\%).

\section{Fractionation}

Am. CME (500 g) of A. macrocephala suspended in distilled water $(400 \mathrm{ml})$ was sequentially fractionated with n-hexane (400 $\mathrm{mL}$ ). For thorough fractionation, process was repeated three times. The same method was followed for obtaining ethyl acetate and chloroform fractions which successively gave $40 \mathrm{~g}(8 \%)$ of $\mathrm{n}$-hexane fraction (Am.NHX), $61.7 \mathrm{~g}$ (12.34\%) of chloroform fraction Am.CHF, $39.4 \mathrm{~g}$ (7.88\%) of ethyl acetate Am.EtOAc and $40.7 \mathrm{~g}(8.14 \%)$ of remaining aqueous fraction (Am.Aq).

\section{Anticholinestrase assays}

For enzyme inhibitory potentials investigation of the Am.CME and its consequent fractions $\mathrm{AChE}$ and $\mathrm{BChE}$ were used following previously reported Ellman's assay [24]. The test samples were dissolved in DMSO (few drops) and further dilution $(125-1000 \mu \mathrm{g} / \mathrm{mL})$ was done in buffer (phosphate, $0.1 \mathrm{M})$. AChE $(518 \mathrm{U} / \mathrm{mg})$ and BChE (7-16 U/mg) were further diluted with $0.1 \mathrm{M}$ buffer (phosphate, $\mathrm{pH} 8.0$ ) till 0.03 
$\mathrm{U} / \mathrm{mL}$ (AChE) and $0.01 \mathrm{U} / \mathrm{mL}$ (BChE). Prepared DTNB $(0.2273 \mathrm{mM})$, BTchI $(0.5$ $\mathrm{mM})$ and ATchI $(0.5 \mathrm{mM})$ solutions in distilled water and stored at $8{ }^{\circ} \mathrm{C}$. Thereafter, added $5 \mu \mathrm{L}$ enzyme solution in cuvette before the addition of test sample $(205 \mu \mathrm{L})$ and $5 \mu \mathrm{L}$ reagent (DTNB) in each essay. Kept this whole mixture for $15 \mathrm{~min}$ at $30^{\circ} \mathrm{C}$ in water bath and substrate solution $(5$ $\mu \mathrm{L})$ was subsequently added. The absorbance was measured spectrophotometrically (Thermo electron corporation, USA) at $412 \mathrm{~nm}$. Galanthamine served as reference standard. Absorbance with the time of reaction was noted at $30^{\circ} \mathrm{Cfor}$ four minutes. The experiment was performed in triplicate. Percent activity of enzyme and inhibition of enzyme by test samples and control were calculated from absorption rate with time change $(\mathrm{V}=$ $\Delta \mathrm{Abs} / \Delta \mathrm{t})$ as:

Enzyme inhibition $(\%)=100-\%$ enzyme activity

Enzyme activity $(\%)=100 \times \mathrm{V} / \mathrm{V}_{\max }\left(\mathrm{V}_{\max }=\right.$ Enzyme activity without inhibitor drug).

\section{Cyclo-oxygenase inhibition assays}

Cyclo-oxygenase enzymes (COX-1, COX-2) inhibition assays were conducted as previously described [25]. The controls contained solvent blank and background correction reaction for enzymes inactivation with $\mathrm{HCl}$ on ice prior to arachidonic acid (16 $\mathrm{Ci} / \mathrm{mol} ; 30 \mathrm{M}$ ) addition. Indomethacin was used as a reference drug (100 mg/mL). Crude extract and subsequent fractions were tested at $62.5-1000 \mathrm{mg} / \mathrm{mL}$ concentrations. COX inhibition was calculated via comparing radioactivity quantity of sample to blank using through the formula as:

COX inhibition $(\%)=\left\{1-\left(\mathrm{DPM}_{\text {extract }}-\mathrm{DPM}_{\text {background }} /\right.\right.$ DPM $_{\text {solvent blank }}-$ DPM $\left.\left._{\text {background }}\right)\right\} \times 100$

where DPM is disintegrations per min of extract, background and solvent blank. Results are given as means of three experiments and values are given as percentage mean \pm standard error mean.

\section{Statistical analysis}

Sample concentration causing $50 \%$ inhibition $\left(\mathrm{IC}_{50}\right)$ was calculated through Microsoft Excel program. Two way ANOVA followed post Bonferroni test for comparingtest groups with positive reference standardswas applied. $\mathrm{P}$ value $<0.05$ was considered significantstatistically. Graphs were drawn through GraphPad Prism.

\section{Results and discussion}

The acetylcholinesterase inhibitory potentials of Am.CME and subsequent fractions of A. macrocephala are summarized in Figure 1. Among all the tested samples, Am.CHF showed the highest percent acetylcholinesterase inhibition, causing $85.76 \pm 1.49$ percent inhibition at $1000 \mu \mathrm{g} / \mathrm{mL}$ concentration. This was followed by Am.EtOAc and Am.CME with $77.50 \pm 0.86$ and $71.00 \pm 1.15$ percent inhibition, respectively at $1000 \mu \mathrm{g} / \mathrm{mL}$ concentration. Galanthamine showed 94.45 \pm 2.37 percent inhibition at $1000 \mu \mathrm{g} / \mathrm{mL}$ concentration. All samples showed good to moderate percent enzyme inhibition in a concentration dependent manner. Butyrylcholinesterase inhibition results of all the samples of $A$. macrocephala are summarized in Figure 2. Among all the samples, Am.CHF caused maximum percent butyrylcholinesterase inhibition which was $82.56 \pm 0.68 \%$ at $1000 \mu \mathrm{g} / \mathrm{mL}$ concentration. Similarly EtOAc, Am.CME and Am.Aq showed 73.56 $\pm 1.56,68.55 \pm$ 0.81 and $67.57 \pm 0.82$ percent enzyme inhibition respectively at $1000 \mu \mathrm{g} / \mathrm{mL}$ concentration. All samples showed enzyme inhibition in concentration dependent manner and were from moderate to good. Standard galanthamine showed $94.45 \pm 2.37$ percent inhibition at $1000 \mu \mathrm{g} / \mathrm{mL}$. Central cholinergic system is considered to be very important in cognitive functions regulation. Cholinergic neuronal loss is the main characteristic of $\mathrm{AD}$ and augmentation of 
central cholinergic action by use of anticholinesterase, is currently the basis of pharmacotherapy of senile dementia of Alzheimer type [26]. AChE is among the fastest identified enzymes that catalyzes the breakage of acetylcholine after depolarization in synaptic cleft. AChE inhibitors such as galanthamine, are frequently used in $\mathrm{AD}$ pharmacotherapy.
The BChE, less specific, has freshly been a center of research, since its concentration remains the same, or is even up-regulated, whereas, AChE is down-regulated dramatically in AD patients [27]. Thus, regulating Ach level via $\mathrm{AChE}$ and $\mathrm{BChE}$ inhibition is considered to be a useful therapeutic approach in treatment of AD and several other types of dementia.

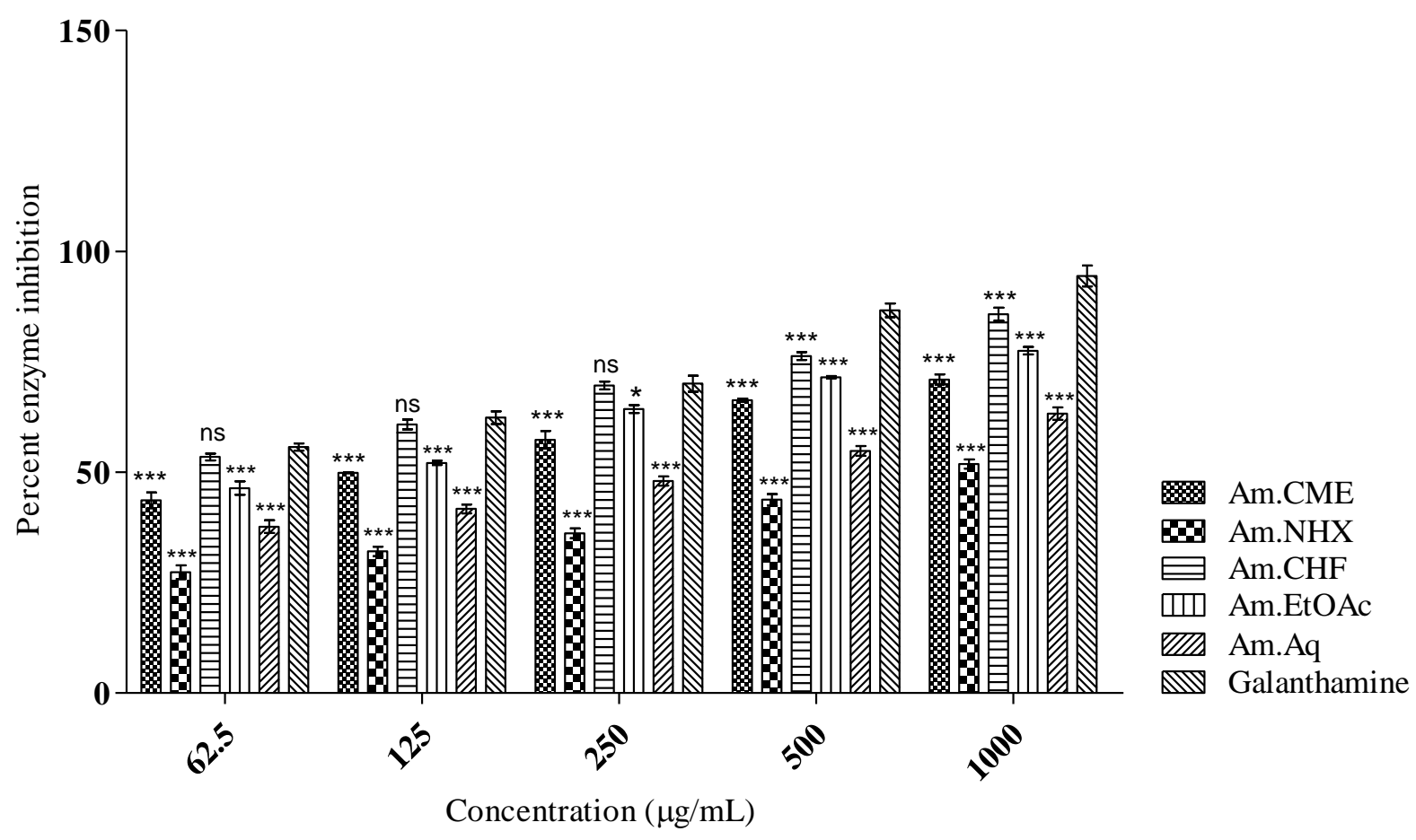

Figure 1. The acetylcholinesterase inhibitory potentials of Am.CME and subsequent fractions of $A$. macrocephala

The history related to drug discovery shows that plants possess active constituents which have become novel sources for investigation in pharmaceutical firms. Plant constituents may not act only synergistically with other constituents rather also work against toxic effects of constituents [28]. In traditional medicine system, several plant species are used in treatment of cognitive disorders, along with neurodegenerative ailment and several neuro-pharmacological ailments [29]. According to a scientific report, Chinese remedy of herbal nature, Yokukansan, used in treatment of several neurological conditions is very efficient having no adverse effects [30]. An alkaloid from snowdrop, galanthamine, has been permitted by the FDA (Food and Drug Administration) of the United States in treatment of $\mathrm{AD}$ [31]. As $\mathrm{AD}$ is becoming a burden of public health, and also the normally available synthetic drugs possess unwanted adverse-effects, new treatment strategies rooted in medicinal plants have been the subject of current study.In present study; we screened A. macrocephala Am. $\mathrm{CME}$ and subsequent fractions for $\mathrm{AChE}$ and $\mathrm{BChE}$ inhibitory potentials. Among all the tested samples, Am. CHF and Am. EtOAc showed remarkable results against 
both the enzymes and were quite comparable with the standard galanthamine. Am. CHF and Am. EtOAc showed $85.76 \pm$ 1.49 and $77.50 \pm 0.86$ percent $\mathrm{AChE}$ inhibition respectively at $1000 \mu \mathrm{g} / \mathrm{mL}$ concentration. Similarly they also caused
$82.56 \pm 0.68$ and $73.56 \pm 1.56$ percent $\mathrm{BChE}$ inhibitions respectively at $1000 \mu \mathrm{g} / \mathrm{mL}$ concentration. The sample Am.Aq showed $71.00 \pm 1.15$ and $68.55 \pm 0.81$ percent $\mathrm{AChE}$ and $\mathrm{BChE}$ inhibition respectively at $1000 \mu \mathrm{g} / \mathrm{mL}$ concentration.

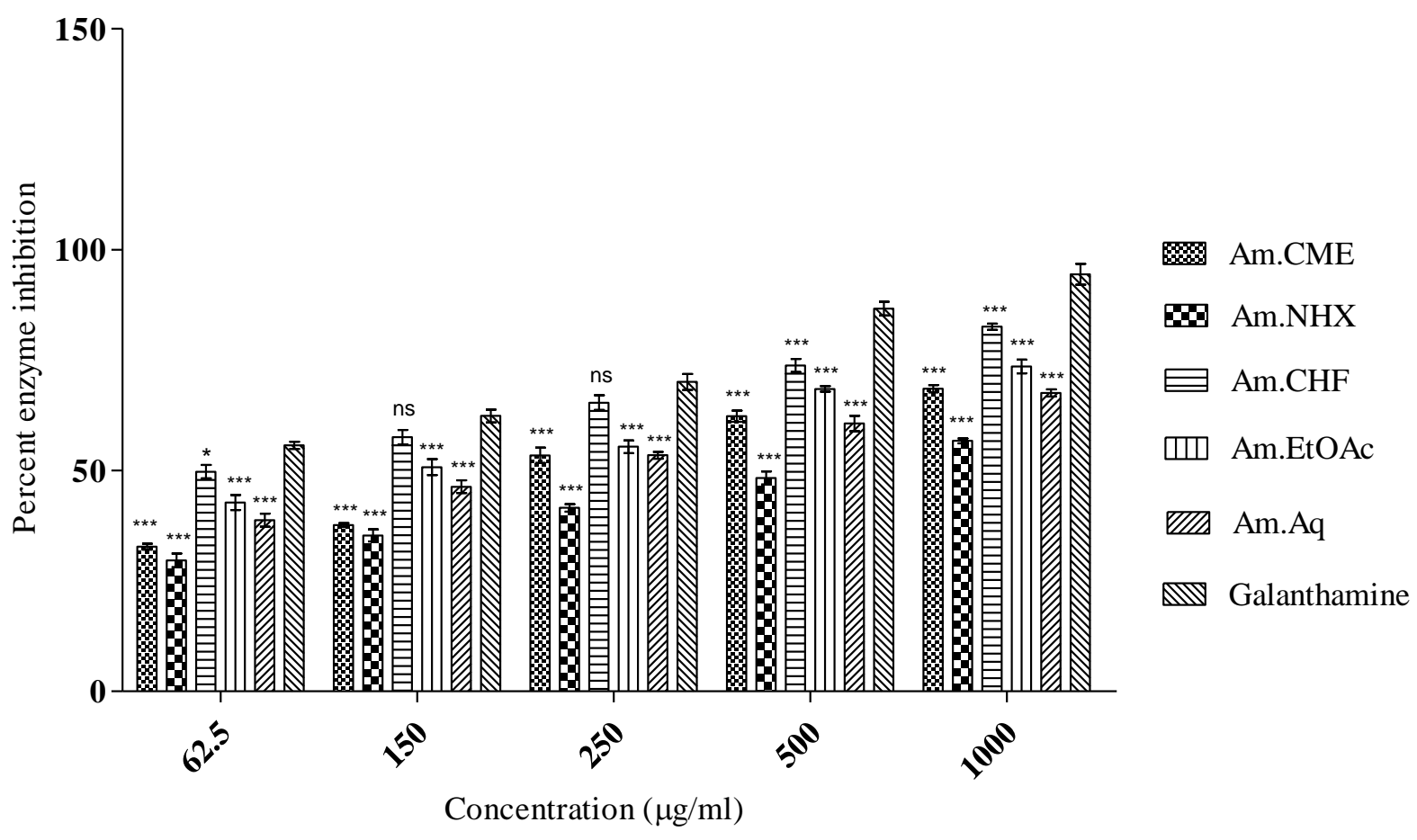

Figure 2. The butyrylcholinesterase inhibitory potentials of Am.CME and subsequent fractions of $A$. macrocephala

Prostanoids are bioactive constituents composed of prostaglandins (PGs), thromboxane and prostacyclin. They are originated from arachidonic acid, which come out from plasma membrane phospholipids intracellularly due to damage of tissue and inflammation. This arachidonic acid converted to the precursors of PGs. PGs, the last metabolites of arachidonic acid, are responsible for the generation of pain. Enzymes like LOX and COX are involved in the formation of these PGs [32]. Before going to test the samples for analgesic activities, their in-vitro screening against COX enzyme is imperative as these types study can predict the in-vivo fate of the test samples. Novel, clinically effective and economically cheap anti-inflamatory and antinociceptive drugs from medicinal plants are the best alternative to the hazardous synthetic drugs. The in vitro cyclooxygenase assays, the crude extract and subsequent fraction of Artemisia macrocephala showed COX-1 and COX-2 inhibition in a dose dependent manner. Among all tested samples, Am.CHF and Am.CCME showed the enhanced inhibition activity against both COX-1 and COX-2. While other fractions showed moderate percent inhibition of the enzymes. Am.CHF and $\mathrm{Am}$. CCME caused $75.23 \pm 0.98\left(\mathrm{IC}_{50}\right.$ $122 \mu \mathrm{g} / \mathrm{mL})$ and $73.33 \pm 0.46 \%\left(\mathrm{IC}_{50} 241\right.$ $\mu \mathrm{g} / \mathrm{mL}$ ) COX-1 inhibition respectively at $1000 \mu \mathrm{g} / \mathrm{mL}$ concentration. Similarly against 
COX-2, they showed 81.23 $\pm 1.23 \quad\left(\mathrm{IC}_{50}\right.$ $60.25 \mu \mathrm{g} / \mathrm{mL})$ and $79.40 \pm 0.46 \% \quad\left(\mathrm{IC}_{50}\right.$ $112.97 \mu \mathrm{g} / \mathrm{mL}$ ) respectively at $1000 \mu \mathrm{g} / \mathrm{mL}$ concentration as shown in Table 1. Am.Aq showed the lowest inhibitory activity for both the enzymes even the highest concentrations. The in-vitro enzyme inhibition activity of the plant can be attributed to the presence of bioactive compounds like flavonoids and terpenes in the plant as reported earlier [20]. The inhibition of COX exhibited by the crude extract and subsequent fractions of Artemisia macrocephala make it as alternative candidate for further work in search for new anti-nociceptive and antiinflammatory compounds.

Table 1. The COX inhibitory potentials of A. macrocephala

\begin{tabular}{|c|c|c|c|c|c|}
\hline Sample & Conc $(\mu \mathrm{g} / \mathrm{ml})$ & COX $1 \%$ inhibition & $\mathrm{IC}_{50} \mu \mathrm{g} / \mathrm{ml}$ & COX $2 \%$ inhibition & $\mathrm{IC}_{50} \mu \mathrm{g} / \mathrm{ml}$ \\
\hline \multirow[t]{5}{*}{ Am.CME } & 1000 & $73.33 \pm 0.46^{* * *}$ & \multirow{5}{*}{241} & $79.40 \pm 0.46^{* * *}$ & \multirow{5}{*}{112.97} \\
\hline & 500 & $61.84 \pm 0.27^{* *}$ & & $72.34 \pm 0.27^{* *}$ & \\
\hline & 250 & $51.85 .44 \pm 1.99^{* *}$ & & $64.64 \pm 1.99^{* *}$ & \\
\hline & 125 & $46.35 \pm 2.24$ & & $55.32 \pm 3.21$ & \\
\hline & 62.5 & $31.23 \pm 1.45$ & & $23.45 \pm 1.15$ & \\
\hline \multirow[t]{5}{*}{ Am.NHX } & 1000 & $41.13 \pm 0.98^{* * *}$ & \multirow[t]{5}{*}{ - } & $39.13 \pm 0.90^{* * *}$ & \multirow{5}{*}{ - } \\
\hline & 500 & $39.15 \pm 2.88^{* *}$ & & $30.15 \pm 2.04^{* *}$ & \\
\hline & 250 & $33.81 \pm 2.75^{* *}$ & & $27.81 \pm 2.35^{* *}$ & \\
\hline & 125 & $29.05 \pm 2.33^{* *}$ & & $21.05 \pm 2.08^{* *}$ & \\
\hline & 62.5 & $27.30 \pm 2.85$ & & $17.30 \pm 2.13$ & \\
\hline \multirow[t]{5}{*}{ Am.CHF } & 1000 & $75.23 \pm 0.98^{* * *}$ & \multirow[t]{5}{*}{122} & $81.23 \pm 1.23^{* * *}$ & \multirow{5}{*}{60.85} \\
\hline & 500 & $71.15 \pm 2.88^{* *}$ & & $74.15 \pm 1.03^{* *}$ & \\
\hline & 250 & $64.65 \pm 2.75^{* *}$ & & $69.65 \pm 1.94^{* *}$ & \\
\hline & 125 & $51.05 \pm 2.33^{* *}$ & & $58.05 \pm 1.23^{* *}$ & \\
\hline & 62.5 & $48.35 \pm 2.85$ & & $51.35 \pm 1.05$ & \\
\hline \multirow[t]{5}{*}{ Am.EtOAc } & 1000 & $71.87 \pm 1.50^{* * *}$ & \multirow[t]{5}{*}{196} & $75.87 \pm 2.06^{* *}$ & \multirow{5}{*}{117.59} \\
\hline & 500 & $70.76 \pm 2.10^{*}$ & & $75.76 \pm 1.90^{*}$ & \\
\hline & 250 & $63.65 \pm 1.89$ & & $71.65 \pm 2.09$ & \\
\hline & 125 & $49.15 \pm 1.99$ & & $53.15 \pm 2.90$ & \\
\hline & 62.5 & $39.44 \pm 2.00$ & & $37.44 \pm 1.90$ & \\
\hline \multirow{5}{*}{ Am.Aq } & 1000 & $46.88 \pm 1.50^{* *}$ & \multirow[t]{5}{*}{-} & $49.88 \pm 2.09^{* * *}$ & \multirow[t]{5}{*}{ - } \\
\hline & 500 & $41.99 \pm 2.10^{*}$ & & $45.99 \pm 1.90^{*}$ & \\
\hline & 250 & $39.65 \pm 1.89$ & & $40.65 \pm 2.09$ & \\
\hline & 125 & $35.15 \pm 1.99$ & & $31.15 \pm 2.09$ & \\
\hline & 62.5 & $31.44 \pm 2.00$ & & $23.44 \pm 1.90$ & \\
\hline Indomethacin & 100 & $82.56 \pm 1.40$ & - & $86.77 \pm 1.64$ & - \\
\hline
\end{tabular}

\section{Conclusion}

The results of the present study show that the plant is rich in bioactive compounds which are responsible for enzymes inhibition activity. From the results of this study, it can be concluded that the plant can be used to treat cognitive disorders, including neurodegenerative diseases and different neuro-pharmacological disorders. This primary screening will further open new channels for the isolation, structural characterization and in-vivo evaluation of the bioactive compounds for enzymes inhibition potentials and then ultimately will lead the molecular level investigation for enzymes inhibition responsible for $\mathrm{AD}$, other forms of dementia and nociception.

\section{Authors' contribution}

Conceived and designed the experiments: I Shah, Performed the experiments: I Shah, M Shoaib, N Ali \& SWA Shah, Analyzed the data: I Shah \& M Shoaib, Contributed 
reagents/materials/analysis tools: I Shah, N Ali \& MA Nawaz, Wrote the paper: I Shah, MA Nawaz \& H Rehman.

\section{References}

1. Hodges JR (2006). Alzheimer's centennial legacy: origins, landmark sand the current status of knowledge concerning cognitive aspects. Brain 129:2811-22.

2. Loizzo MR, Tundis R, Menichini F \& Menichini F (2008). Occurring natural products and their derivatives as cholinesterase inhibitors in the treatment of neurodegenerative disorders: an update. Curr Med Chem 15:1209-28.

3. Filho JMB, Medeiros KCP, Diniz MFFM, Batista LM, Athayde-Filho PF, Silva MS, da-Cunha EVL, Almeida JRGS \& Quintans-Junior LJ (2006). Natural products inhibitors of the enzyme acetylcholinesterase. $\mathrm{Braz} \quad J$. Pharmacogn.16(2): 258-285

4. Giacobini E (2003). Cholinergic function and Alzheimer'sdisease. Inter $J$ Geriatr Psych 18: S1-S-5.

5. Orhan I, Kartal M, Naz Q, Ejaz A, Yilmaz G, Kan Y, Konuklugil B, Sener B \& Choudhary MI (2007). Antioxdant and anticholinesterase evaluation of selected Turkish Salvia species. Food Chem 103: 1247-1254.

6. Heinrich M \& Teoh HL (2004). Galanthamine from snowdrop-the development of a modern drug against Alzheimer's disease from local Caucasian knowledge. J Ethnopharma 92: 147-162.

7. Pope C, Karanth S \& Liu J (2005). Pharmacology and toxicology of cholinesterase inhibitors: uses and misuses of a common mechanism of action. Environ Toxicol Pharmacol 19(3): 433-46.

8. Van Marum RJ (2008). Symptomatic treatment in patients with dementia: light, but not melatonin, is probably worthwhile. Ned Tijdschr Geneeskd 152(43):23224.

9. Giacobini E (2004). Cholinesterase inhibitors: new roles and therapeutic alternatives. Pharmacol 50(4): 433-40.

10. Okello EJ, Savelev SU \& Perry EK, (2004). In vitro anti-beta-secretase and dual anticholinesteraseactivities of Camellia sinensis L. (tea) relevant to treatment of dementia. Phytother 18: 624627.

11. Kamal MA, Qu X, Yu QS, Tweedie D, Holloway HW, Li Y, Tan Y\& Greig NH, (2008).Tetrahydrofurobenzofurancymseri ne, a potent BuChE inhibitor \& experimental Alzheimer drug candidate, enzyme kinetic analysis. J Neural Transm 115(6): 889-98.

12. Silman I \& Sussman JL (2005). Acetylcholinesterase: 'classical' and 'nonclassical' functions and pharmacology. Curr Opin Pharmacol 5: 293-302.

13. Rountree SD, Chan W, Pavlik VN, Darby EJ, Siddiqui S \& Doody RS (2009). Persistent treatment with cholinesterase inhibitors slows the progression of AD. Alzheimers Res Ther 1(2): 7-10.

14. Zareh M (2005). Synopsis of the family astereace. Int J Agric Biol 5: 832-44.

15. Polya GM (2003). Biochemical targets of plant bioactive compounds. In: A pharmacological reference guide to sites of action and biological effects. CRC Press, Florida.

16. Iwalewa EO, Mc Gaw LJ, Naidoo V \& Eloff JN (2007). Inflammation: the foundation of diseases and disorders. A review of phytomedicines of South African origin used to treat pain and inflammatory conditions. Afr $J$ Biotechnol 6:2868-2885.

17. Fiorucci S, Meli R, Bucci M \& Cirino G (2001). Dual inhibitors of cyclooxygenase \& 5-lipoxygenase. A new 
avenue in anti-inflammatory therapy? Biolog Pharmacol 62: 1433-1438.

18. Rang HP \& Dale MM (1987). Pharmacology. Churchill Livingstone, Edinburgh.

19. Dudko V, Berezovskaya $T$ \& Usynina $R$ (1974). Essential oil from Artemisia macrocephala. Chem Nat Compd 10:10007.

20. Ali N, Shah SWA \& Shah I (2011). Preliminary phytochemical screening and antispasmodic activity of Artemisia macrocephala Jacquem. JYP. 3:125-128.

21. Ali N, Shah I, Shah SWA, Ahmed G, Shoaib M, Junaid M, Ali W \& Ahmed Z (2013). Antioxidant and relaxant activity of fractions of crude methanol extract and essential oil of Artemisia macrocephala Jacquem. BMC Complem Altern Med 13(96):13-96.

22. Shoaib M, Shah I, Ali N, Wadood SWA \& Shah A (2015). In vitro acetylcholinesterase and butyrylcholinesterase inhibitory potentials of essential oil of Artemisia macrocephala. Bangladesh J Pharmacol 10:87-91.

23. Ellman GL, Courtney KD \& Featherstone RM (1961). A new and rapid colorimetric determination of acetylcholinesterase activity. Biochem Pharmacol 7: 88-95.

24. Siddiqui MF \& Levey AI (1999). Cholinergic therapies in Alzheimer's disease. Drugs Future 24:417-44.

25. Aremu AO, Fawole OA, Chukwujekwu JC, Light ME, Finnie JF \& Van Staden J (2010). In vitro antimicrobial, anthelmintic and cyclo-oxygenase - inhibitory activities and phytochemical analysis of Leucosidea sericea. $J$ Ethnopharmacol 131: 22-27.

26. Giacobini E (2004). Cognitive enhancing drugs. Bucca Fusco JJ, editor. Birkh"auser, Verlag: Basel-BostonBerlin.

27. Howes MJ \& Houghton PJ (2003). Plants used in Chinese and Indian traditional medicine for improvement of memory and cognitive function. Pharmacol Biochem Behav 75: 513-527.

28. Mukherjee PK, Kumar V, Mal M \& Houghton PJ (2007a). Acetylcholinesterase inhibitors from plants. Phytomedicine 14: 289-300.

29. De Caires S \& Steenkamp V (2010): Use of Yokukansan (TJ-54) in the Treatment of Neurological Disorders: A Review. Phytother 10: 3146.

30. Adewusi EA, Moodley N \& Steenkamp V (2010). Medicinal plants with cholinesterase inhibitory activity: A Review, Afr J Biotechnol 9(49): 82578276.

31. Hong K, Berruezo SA, Poungvarin N, Oliva A, Vatta M, Burgada J, Burgada P, Towbin JA, Dumaine R, Pinero GC, Antzelevitch C \& Burgada R (2004). Phenotypic characterization of a large European family with Brugada syndrome displaying a sudden unexpected death syndrome mutation in SCN5A. $J$ Cardiovasc Electrophysiol 15(10): 64-69.

32. Makkar HPS, Sidhuraju P \& Becker K (2007). Plant secondary metabolites. Humana Press Inc New Jersey, USA. 